\title{
The Research and Application of Microbial Degradation Technology on Heavy Oil Reservoir in Huabei Oilfield
}

\author{
Guan Wang ${ }^{1, *}$, Rui Wang $^{1}$, Yaxiu $F u^{2}$, Lisha Duan $^{1}$, Xizhi Yuan ${ }^{1}$, Ya Zheng ${ }^{1}$, Ai $W_{a n g}{ }^{1}$, Ran $H u{ }^{1}$, and Na $S u^{1}$ \\ ${ }^{1}$ Engineering Technology Research Institute, Huabei Oilfield Company of PetroChina, Renqiu, He Bei Province, 062552, China \\ ${ }^{2}$ The Erlian Filiate of Huabei Oilfield Company, Huabei Oilfield Company of PetroChina, Xilinhot, Inner Mongolia, 026000, China
}

\begin{abstract}
Mengulin sandstone reservoir in Huabei oilfield is low- temperature heavy oil reservoir. Recently, it is at later stage of waterflooding development. The producing degree of water flooding is poor, and it is difficult to keep yield stable. To improve oilfield development effect, according to the characteristics of reservoir geology, microbial enhanced oil recovery to improve oil displacement efficiency is researched. 2 microbial strains suitable for the reservoir conditions were screened indoor. The growth characteristics of strains, compatibility and function mechanism with crude oil were studied. Results show that the screened strains have very strong ability to utilize petroleum hydrocarbon to grow and metabolize, can achieve the purpose of reducing oil viscosity, and can also produce biological molecules with high surface activity to reduce the oil-water interfacial tension. 9 oil wells had been chosen to carry on the pilot test of microbial stimulation, of which 7 wells became effective with better experiment results. The measures effective rate is $77.8 \%$, the increased oil is $1,093.5$ tons and the valid is up to 190 days.
\end{abstract}

\section{Introduction}

Mengulin sandstone reservoir in Huabei oilfield is located in Erlian Basin. The average porosity is $22.4 \%$ and the permeability is between 334.8 to $749.7 \mathrm{mD}$. Under the reservoir temperature condition of $35{ }^{\circ} \mathrm{C}$, the crude oil physical property is poor with high viscosity of $179.1 \mathrm{mPa} \cdot \mathrm{s}$, high oil-water viscosity ratio of 259 , high colloid and asphalt quality score of $36.8 \%$ and high density of $0.9012 \mathrm{~g} / \mathrm{cm}^{3}$, being the typical heavy oil reservoir. Since entering the late waterflooding stage, the degree of water driving is poor and stable yield is difficult.

In order to solve the problem of lower waterflooding efficiency caused by huge crude oil viscosity, high oilwater viscosity ratio and poor crude oil liquidity, microbial degradation technology is researched. Through the microbe itself and its metabolites reacting with crude oil to improve product properties, the waterflooding displacement efficiency is improved [1-6].

The key for microbial enhanced oil recovery is to screen excellent strains. Based on the related theories of biological evolution [7-9], living organisms have innate ability of evolutionary and adaptation to the environment. So, selecting from the high colloid and asphalt content environment, through the enrichment and purification, 2 strains of HB-1 and HB-2 is eventually isolated.

\section{Experiment}

\subsection{Test Materials}

\footnotetext{
* Corresponding author: cyy_wangg@petrochina.com.cn
}

Activated medium (LB): peptone of $10.0 \mathrm{~g}$, yeast extract of $5 \mathrm{~g}, \mathrm{NaCl}$ of $10 \mathrm{~g}$, tap water of $1000 \mathrm{ml}$, adjusting $\mathrm{pH}$ to 7.2.

Emulsified medium: yeast extract of $0.5 \mathrm{~g}, \mathrm{NH}_{4} \mathrm{Cl}$ of $3 \mathrm{~g}, \mathrm{KH}_{2} \mathrm{PO}_{4}$ of $0.5 \mathrm{~g}$, glucose of $5 \mathrm{~g}$, peptone of $1.5 \mathrm{~g}$, formation water of $1000 \mathrm{ml}$, crude oil of $50 \mathrm{~g}$.

Viscosity reduction medium: yeast extract of $0.5 \mathrm{~g}$, $\mathrm{NH}_{4} \mathrm{Cl}$ of $3 \mathrm{~g}, \mathrm{KH}_{2} \mathrm{PO}_{4}$ of $0.5 \mathrm{~g}$, glucose of $5 \mathrm{~g}$, peptone of $1.5 \mathrm{~g}$, formation water of $1000 \mathrm{ml}$. The volume ratio of nutrient solution, crude oil and bacteria solution is 1:1:1.

\subsection{Evaluation Method}

1. The adaptability of formation water and strains. LB medium is configured with formation water, and cultivated under formation temperature for 24 hours to observe the bacteria growth.

2. Emulsification test. The isolated bacteria is activated and cultured with LB activated medium for 24 hours and then inoculated on emulsion medium by the volume fraction of $5 \%$. Under temperature of $35^{\circ} \mathrm{C}$, on a table of $200 \mathrm{r} / \mathrm{min}$, it is cultivated for 3 days. Observe the emulsion phenomenon and measure surface tension using TX500C interface tensiometer.

3 . Viscosity reduction test. The isolated bacteria is activated and cultured with LB activated medium for 24 hours, and then inoculated on viscosity reduction medium according to that the volume ratio of nutrient solution, crude oil and bacteria solution is $1: 1: 1$. Under temperature of $35{ }^{\circ} \mathrm{C}$, on a table of $200 \mathrm{r} / \mathrm{min}$, it is cultivated for 7 days. Crude oil viscosity is measured before and after viscosity reduction using the Mars 
rheometer.

\section{Results and Discussions}

\subsection{Compatibility of Strains and Formation Water}

From the water quality analysis of formation water, the formation water type of Mengulin is $\mathrm{NaHCO}_{3}$, and the salinity is $1,301 \mathrm{mg} / \mathrm{L}$. The strains compatibility with formation water test results are shown in table 1. Under formation temperature, after joining strains of HB-1 and HB-2, the number of viable organism is higher than that before compatibility. It shows that strains HB-1 and HB2 have well compatibility with formation water and can reproduce in the formation environment.

Table 1. Compatibility evaluation results.

\begin{tabular}{|c|c|c|}
\hline $\begin{array}{c}\text { Strain } \\
\text { Number }\end{array}$ & $\begin{array}{c}\text { Viable count before } \\
\text { compatibility } \\
\text { (cells/mL) }\end{array}$ & $\begin{array}{c}\text { Viable count after } \\
\text { compatibility } \\
\text { (cells/mL) }\end{array}$ \\
\hline HB-1 & $2.0 \times 10^{3}$ & $2.2 \times 10^{8}$ \\
\hline HB-2 & $2.0 \times 10^{3}$ & $1.1 \times 10^{8}$ \\
\hline
\end{tabular}

\subsection{Emulsion Performance}

Take crude oil from Mengulin as samples, emulsification experiment was carried out. The emulsification effect is shown in table 2 . The crude oil and bacteria liquid are separated after emulsification and determinate its interfacial tension, shown in table 3. After acting of strains HB-1 and HB-2, crude oil and water are emulsified completely. The strains fermentation liquor after oil emulsion has certain surface activity. Compared with the blank, interfacial tension reducing rate of strains fermentation liquor is as high as $77.91 \%$ to $91.05 \%$, which illustrates that HB-1 and HB-2 can produce surface active substance after acting with crude oil to reduce the oil-water interfacial tension.

Table 2. Crude oil emulsion.

\begin{tabular}{|c|c|c|}
\hline $\begin{array}{c}\text { Strain } \\
\text { Number }\end{array}$ & $\begin{array}{c}\text { Well Meng 18- } \\
18\end{array}$ & $\begin{array}{c}\text { Well Meng } \\
21-23\end{array}$ \\
\hline HB-1 & +++++ & +++++ \\
\hline HB-2 & +++++ & +++++ \\
\hline
\end{tabular}

Note: emulsification effect will be divided into 5 levels, the methods are as follows:

Level 5: Oil and water can be completely miscible without oil-water boundary and will not layer standing for a long time.

Level 4: Oil and water can be mostly miscible and can mix basically by forcibly shake. Oil bead have better liquidity.

Level 3: Oil and water can be partly miscible and can mix partly by forcibly shake and then separate from each other quickly. Oil bead is droplets form.

Level 2: Oil and water can be a little miscible. The color of lower water is obviously stronger than the control sample. Oil bead is granular. Level 1: Oil and water separate obviously. The lower water clears. It can't be mutually soluble after shocking forcedly.

\subsection{Viscosity Reduction Property}

Take crude oil from Mengulin as samples, viscosity reduction experiment was carried out. The results are shown in table 4. Strains HB-1 and HB-2 have better viscosity reduction effect. The viscosity reduction rate can reach from $39.8 \%$ to $49.5 \%$.

Table 3. Interfacial tension measurement results.

\begin{tabular}{|c|c|c|c|c|c|}
\hline \multirow{2}{*}{ Well } & \multirow{2}{*}{$\begin{array}{c}\text { Interfacial tension } \\
\text { of the blank } \\
\left(\mathrm{mN} \cdot \mathrm{m}^{-1}\right)\end{array}$} & $\begin{array}{c}|c| \\
\text { HB-1 }\end{array}$ & \multicolumn{2}{c|}{ HB-2 } \\
\cline { 3 - 6 } & & $\begin{array}{c}\text { Interfacial tension } \\
\left(\mathrm{mN} \cdot \mathrm{m}^{-1}\right)\end{array}$ & $\begin{array}{c}\text { Reducing rate } \\
(\%)\end{array}$ & $\begin{array}{c}\text { Interfacial tension } \\
\left(\mathrm{mN} \cdot \mathrm{m}^{-1}\right)\end{array}$ & $\begin{array}{c}\text { Reducing rate } \\
(\%)\end{array}$ \\
\hline $\begin{array}{c}\text { Well Meng } \\
18-18\end{array}$ & 1.9765 & 0.338 & 82.9 & 0.4366 & 77.91 \\
\hline $\begin{array}{c}\text { Well Meng } \\
22-23\end{array}$ & 1.5224 & 0.1362 & 91.05 & 0.2069 & 86.41 \\
\hline
\end{tabular}

Table 4. Viscosity reduction test results.

\begin{tabular}{|c|c|c|c|c|c|}
\hline \multirow{2}{*}{ Well } & \multirow{2}{*}{$\begin{array}{c}\text { Viscosity of the } \\
\text { blank } \\
\mathrm{mPa} \cdot \mathrm{s}\end{array}$} & \multicolumn{2}{|c|}{ HB-1 } & \multicolumn{2}{|c|}{ HB-2 } \\
\cline { 3 - 6 } & $\begin{array}{c}\text { Viscosity } \\
\mathrm{mPa} \cdot \mathrm{s}\end{array}$ & $\begin{array}{c}\text { viscosity reduction } \\
\text { rate } \\
\%\end{array}$ & $\begin{array}{c}\text { Viscosity } \\
\mathrm{mPa} \cdot \mathrm{s}\end{array}$ & $\begin{array}{c}\text { viscosity reduction } \\
\text { rate } \\
\%\end{array}$ \\
\hline $\begin{array}{c}\text { Well Meng } \\
18-18\end{array}$ & 322.2 & 162.7 & 49.5 & 181.1 & 43.8 \\
\hline $\begin{array}{c}\text { Well Meng } \\
22-23\end{array}$ & 293.7 & 172.7 & 41.2 & 176.8 & 39.8 \\
\hline
\end{tabular}

\section{Microbial Mechanism Analysis}


Selecting a set of test with best viscosity reduction effect (i.e. viscosity reduction test of strains HB-1 on well Meng 18-18), component analysis is carried out by gas chromatography. Chromatography conditions is weak polarity column of $30 \mathrm{~m} * 0.32 \mathrm{~mm} * 0.5 \mu \mathrm{m}$, helium flow rate of $1.0 \mathrm{ml} / \mathrm{min}$, sample injection of $0.2 \mu \mathrm{L}$ and vaporization temperature of $260{ }^{\circ} \mathrm{C}$. On column temperature program, the initial temperature is $60{ }^{\circ} \mathrm{C}$. After 3 minutes, the temperature rises up to $260{ }^{\circ} \mathrm{C}$ by rate of $10^{\circ} \mathrm{C} / \mathrm{min}$. The analysis results are shown in Figure 1 and Figure 2.

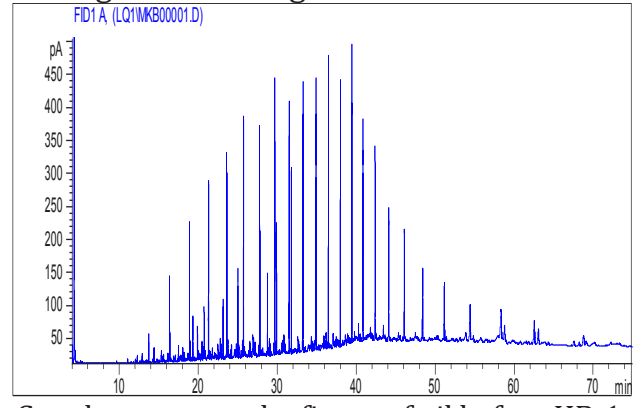

Fig. 1. Gas chromatography figure of oil before HB-1 action.

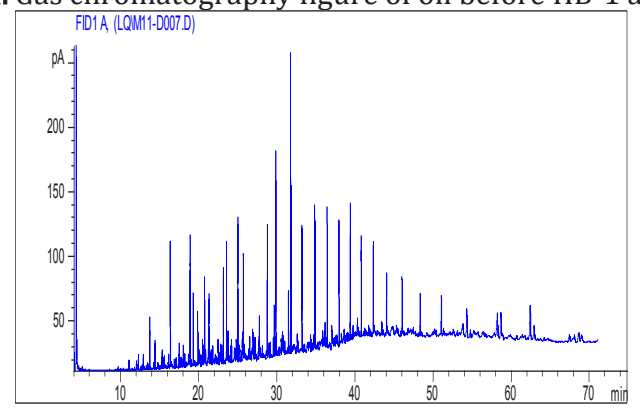

Fig. 2. Gas chromatography figure of oil after HB-1 action.

After microbial action, crude oil is decomposed, the peak of each composition obviously changes, and especially the characteristic peak of long chain hydrocarbon (C21-C50) begins to disappear. It shows that normal alkanes of different carbon chain length in crude oil are degraded by microbial. By chromatographic analysis statistics, pristine to $\mathrm{C} 17$ ratio of crude oil after HB-1 effect rises from $0.49 \%$ to $11.97 \%$ and phytane to $\mathrm{C} 18$ ratio rises from $0.86 \%$ to $22.97 \%$. This suggests that the oil mobility is improved after microbial effect.

Through the paraffin change of crude oil (Figure 3), the mass fraction of different components in crude oil is changed after HB-1 effects. The mass fraction of heavy component significantly lowers and that of light component increases. It shows that HB-1 has a strong ability of growth and metabolism for petroleum hydrocarbon, achieving the purpose of reducing oil viscosity.

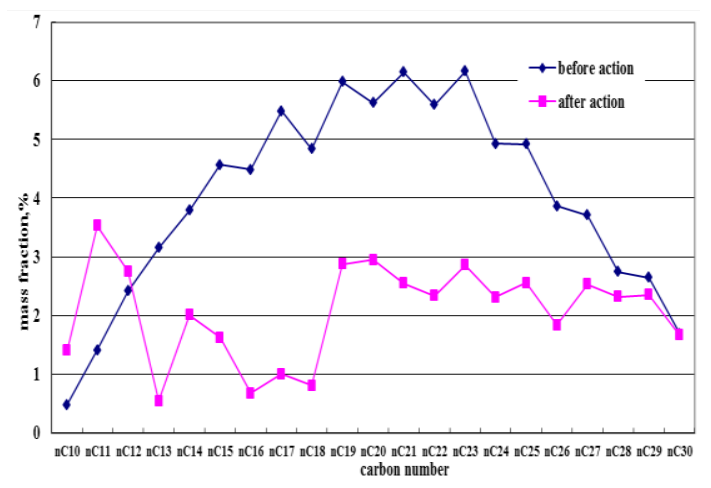

Fig. 3. Paraffin distribution of crude oil before and after HB-1 action.

\subsection{Surface Active Material Analysis Produced by Microbial}

Surface active substance could be produced by microbial metabolism. From FTIR (Figure 4), $3307 \mathrm{~cm}^{-1}$ is $\mathrm{NH}$ contraction vibration caused by hydrogen bonding between molecular chain, $3070 \mathrm{~cm}^{-1}$ is $\mathrm{NH}$ stretching band caused by intramolecular hydrogen bonding in N-H group, $1539 \mathrm{~cm}^{-1}$ and $1648 \mathrm{~cm}^{-1}$ is amide band I and II respectively. These characteristic absorption shows that the hydrophilic group of surfactant molecules is a peptide chain. $2856 \mathrm{~cm}^{-1}-2957 \mathrm{~cm}^{-1}$ and $1387 \mathrm{~cm}^{-1}$ $1463 \mathrm{~cm}^{-1}$ is $\mathrm{C}-\mathrm{H}$ stretching vibration of absorption aliphatic carbon chain. $1203 \mathrm{~cm}^{-1}$ and $1735 \mathrm{~cm}^{-1}$ are characteristic absorption of lactone. These show that the hydrophobic group of surfactant molecules is halfmolecule fatty acid. Thus the surfactant molecule is inferred acyclic lipopeptide molecule. The microbe produces surfactant after acting with crude oil to reduce the oil-water interfacial tension and scatter oil with emulsifying ability.

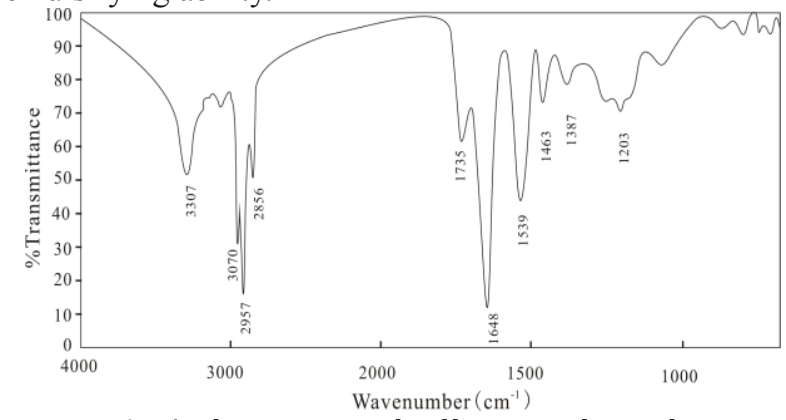

Fig. 4. The FT-IR graph of lipopeptid sample.

\section{MEOR Field Applications}

On May 2nd to April 27th 2013, in Mengulin oilfield, nine oil wells were chosen to carry on the pilot test of microbial stimulation, of which 7 wells became effective and the effective rate is $77.8 \%$. In working wells, the average daily fluid rose from 81.34 tons to 103.96 tons, the average daily oil rose from 11.69 tons to 20.68 tons, and the average watercut decreased from $85.62 \%$ to $85.62 \%$. The increased oil is $1,093.5$ tons and the valid is up to 190 days. 


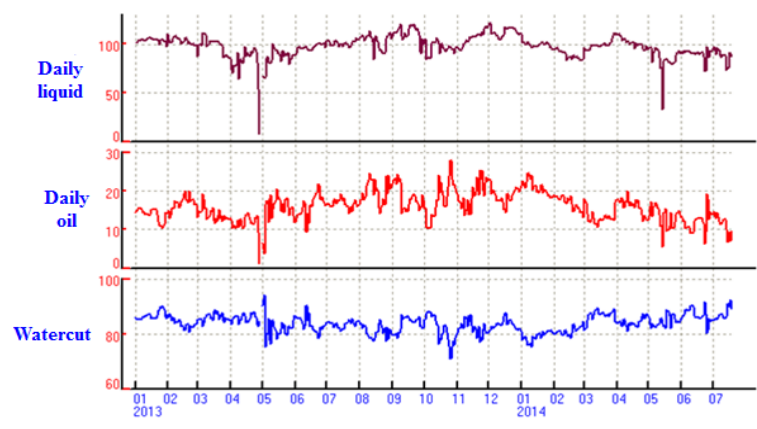

Fig. 5. Production situations of effective oil wells.

Table 5 The crude oil change before and after simulation

\begin{tabular}{|c|c|c|c|c|}
\hline & $\begin{array}{c}\text { Viscosit } \\
\mathrm{mPa}\end{array}$ & $\begin{array}{c}\text { Interfaci } \\
\text { al } \\
\text { tension } \\
\left(\mathrm{mN} \cdot \mathrm{m}^{-}\right. \\
1)\end{array}$ & $\begin{array}{c}\text { Wax } \\
\text { mass } \\
\text { score } \\
(\%)\end{array}$ & $\begin{array}{c}\text { Colloid } \\
\text { and } \\
\text { asphalt } \\
\text { mass } \\
\text { score } \\
(\%)\end{array}$ \\
\hline $\begin{array}{c}\text { Before } \\
\text { simulati } \\
\text { on }\end{array}$ & 203.2 & 2.742 & 10.9 & 38.2 \\
\hline $\begin{array}{c}\text { After } \\
\text { simulati } \\
\text { on }\end{array}$ & 111.5 & 0.689 & 6.6 & 30.1 \\
\hline
\end{tabular}

From crude oil changes conditions before and after measures, the average viscosity of crude oil dropped from $203.2 \mathrm{mPa} \cdot \mathrm{s}$ to $111.5 \mathrm{mPa} \cdot \mathrm{s}$, wax content of crude oil fell from $10.9 \%$ to $6.6 \%$, colloid asphalt content fell from $38.2 \%$ to $30.1 \%$ and oil-water interfacial tension decreased from by $2.742 \mathrm{mN} / \mathrm{m}$ to $0.689 \mathrm{mN} / \mathrm{m}$. The results show that the microbial degrades part of heavy components of formation crude oil, improves the liquidity of crude oil, and produces surface active substance.

\section{6 conclusions}

(1) According to the reservoir characteristics, 2 strains are optimized which can adapt to reservoir environment and reproduce massively.

(2) Microbe can improve crude oil properties after acting with formation crude oil. The light component increases and the heavy component decrease. The produced surfactants substances have emulsification ability to scattering oil, to reduce the oil-water interfacial tension and further improve the liquidity of crude oil.

(3) The microbial stimulation in Mengulin oilfield has apparent effective, showing that MEOR can improve oil displacement efficiency and recovery efficiency. It provides theoretical and practical support for implementation of microorganism to improve oil displacement efficiency of heavy oil reservoirs. MEOR can be the effective means to increase production at late stage of waterflooding development.

\section{References}

1. Wang C M, Li D P, Liu S G. Effects of Biophysiological and Biochemical Characteristics of a Strain of Microbacterium SP.on Properties of
Thickened Oil[J]. Acta Petrolei Sinica, 2007, 28(5): 89-92.

2. Zhang Y S, Lan G Z, Deng L, et al. Experiments on Heaving Oil Degradation and Enhancing Oil Recovery by Microbial Treatments[J]. Acta Petrolei Sinica, 2001, 22(1): 54-57.

3. Yu J, Chen A H, Ma T L, et al. Analytic Mehtod of Oil Microbes and Their Metablizing Substances in the Third Oil Recovery[J]. Xinjiang Oil \& Gas, 2008, 4(4): 88-92.

4. Li X M, Luan J Z, Xiao X M. Physical Simulation Situation of Microbe Oil Recovery Technology[J]. Oil Drilling \& Production Technology, 2006, 28(1): 9-12.

5. Chen T, Yang S Z, MU B Z. Determination of Lipopeptide Surfactants in Cell-Free Broth[J]. Oilfield Chemistry, 2004, 21(4): 385-389.

6. Han S, Fu B F, Li C, et al. Characteristics and Field Application of Bio-Surfactant Produced by Bacillus subtilis BIT-BS002[J]. Journal of Microbiology, 2012, 32(4): 24-29.

7. Deng Z S, Ren G M, Zhang B C. Microorganism Screening for Petroleum Degradation and Their Degrading Capability in Shanbei Oil-field[J]. Journal of Yanan University(Natural Science Edition), 2005, 24(3): 65-67.

8. Luo J B, Wu W X,Zhang $\mathrm{F}$, et al. Isolation and Metabolite Analysis of A Strain Producing Lipopeptide Biosurfactant[J]. Chemistry \& Bioengineering, 2010, 27(2): 46-49.

9. Wen S C, Li X S, He S L, et al. Laboratory Evaluation of Bacterial Species for MEOR and Analysis of Their Field Results[J]. Oilfield Chemistry, 2009, 26(2): 195-198. 